\title{
Effect of Different Time of Sowing and Weed Management Methods on Weed Interference, Productivity and Profitability of Bt Cotton in Western Zone of Tamil Nadu
}

\author{
V. Hariharasudhan* and C. Chinnusamy \\ Department of Agronomy, \\ Tamil Nadu Agricultural University, Coimbatore-641 003
}

\begin{abstract}
A field experiment was conducted at Tamil Nadu Agricultural University; Coimbatore during winter season of 2015-16 and 2016-17 to evaluates the influence of time of sowing and weed management on weed interference and productivity, profitability of Bt cotton hybrid. Result reveled that, Distinctive time of sowing in cotton impact the weeds and cotton growth. Advance sowing of cotton ( $1^{\text {st }}$ August) with pre-emergence application of pendimethalin $38.7 \%$ CS followed by post-emergence pyrithiobac sodium $5 \%$ EC $62.5 \mathrm{~g} / \mathrm{ha}$ significantly recorded lower total weed density and dry weight and better crop growth, higher seed cotton yield, net return and B: $C$ ratio in both years of the experiment.
\end{abstract}

Key words: Bt cotton,Western Zone of Tamil Nadu, Time of sowing, Weed management.

Cotton (Gossypium hirsutum L.) is an important commercial crop of India; it sustains the cotton textile industry which perhaps the largest segment of organized industries in the country. Cotton is highly sensitive to environmental conditions and grown in a wide range of ecological zones. In cotton, $60 \%$ of the yield losses are due to climate as compared to $30 \%$ recorded in other crops like cereals, oilseeds and pulses (Dason, 1996). Predicting plant responses to changing atmospheric $\mathrm{CO} 2$ and to the possible global warming by high temperature and their interaction are more important than sole effect. Temperature is the driving force of all cellular reactions. Optimum temperature range promotes plant health through active growth. Undesirable temperatures can slowdown the growth and lead to declining effects. In addition, temperature can influence the competitive outcome between desirable cotton and weeds.

Weeds primarily compete during the early crop growth period for solar radiation, moisture and nutrients. The critical period of weed competition in cotton was found to be 15 to 60 days (Rajiv Sharma, 2008). Since, the cotton has long development cycle; it needs to go through incessant downpours and along these lines weeds additionally represent a difficult issue. Losses caused by weeds in cotton ranges from 50 to 85 per cent depending upon the nature and intensity of weeds.

Sowing time plays an important role to realize maximum seed cotton yield as the potential optimum yield is directly influenced by the accumulation of heat units and thermal time (Zhang et al., 2008). It is essential to study the quantitative relationships which account for the effects of plant and environmental factors on reproductive allocation. In central India,

*Corresponding author email: tnauhari@gmail.com if sowing is delayed beyond 15th July, the peak flowering and boll development period will coincide with cool day and night temperatures (Hebbar et al., 2007). Hence, in order to manage the crop better, it is worthwhile to understand the effect of sowing dates on phenology and weeds interference of $\mathrm{Bt}$ cotton hybrid.

\section{Material and Methods}

Field experiment was conducted at Tamil Nadu Agricultural University, Coimbatore.The farm is situated in Western Agro climatic zone of Tamil Nadu and located with $11^{\circ} \mathrm{N}$ longitude and $77^{\circ} \mathrm{E}$ latitude at an altitude of $426.7 \mathrm{~m}$ above mean sea level and the farm receives the normal total annual rainfall of $674.2 \mathrm{~mm}$ in 45.8 rainy days. Trial was conducted in sandy clay loam type of soil and it was medium in organic carbon content and the available nutrient status was low in nitrogen, medium in phosphorus and high in potassium.

\section{Experimental design and treatments}

Experiment consisting four dates of sowing ( $1^{\text {st }}$ and $15^{\text {th }}$ August and $1^{\text {st }}$ and $15^{\text {th }}$ September) in the main plots and six weed control treatments (preemergence pendimethalin $30 \%$ EC \& $38.7 \%$ CS of 1.0 and $0.68 \mathrm{~kg} / \mathrm{ha}$ followed by post-emergence pyrithiobac sodium 5\% EC $62.5 \mathrm{~g} / \mathrm{ha}$ and quizalofop ethyl $5 \%$ EC $50 \mathrm{~g} / \mathrm{ha}$ at 2-3 leaf stages of weeds, Hand weeding on 20 and 40 DAS and weedy check in the sub-plots. Trial was laid out in split plot design with three replications. The land was prepared for cotton by giving two dry ploughings with disc plough followed by clod crushing to achieve fine seed bed. Cotton was sown manually keeping the distance of $90 \mathrm{~cm} \times 60 \mathrm{~cm}$ in different time of sowing. Immediately after the sowing, light irrigation was given for uniform 
germination. Pre-emergence herbicides were sprayed on 3 DAS and post- emergence herbicides were sprayed at 2-3 leaf stages of weeds in respect of treatment using hand operated knapsack sprayer fitted with a flat fan type nozzle with spray volume of 500 litres /ha. Growing Degree Days (GDDs) were calculated as per the formula developed by Jones and Wells (1998)

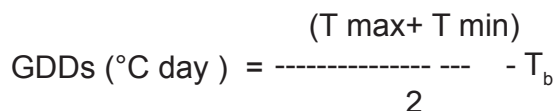

Whereas,

$\mathrm{T}_{\text {max }}$ :Daily maximum temperature $\left({ }^{\circ} \mathrm{C}\right)$

$\mathrm{T}^{\mathrm{min}}$ : Daily minimum temperature $\left({ }^{\circ} \mathrm{C}\right)$

$\mathrm{T}_{\mathrm{b}}$ :Base temperature as $15.5^{\circ} \mathrm{C}$

Densities of grasses, sedges and broad leaved weeds were counted using $0.5 \mathrm{~m} \times 0.5 \mathrm{~m}$ quadrat from four randomly fixed places in each plot and collected weeds were shade dried in hot-air oven at $80^{\circ} \mathrm{C}$ for 72 hours. The weed density $\left(\mathrm{No}^{-2}\right)$ and dry weight $\left(\mathrm{g} \cdot \mathrm{m}^{-2}\right)$ were recorded separately. Weed control efficiency (WCE) was calculated as per the procedure given by Mani et al. (2007).

$$
\text { WCE }=\frac{\text { WDc }- \text { WDt }}{\text { WDc }} \times 100
$$

Whereas,

WCE: weed control efficiency (\%), WDc: weed dry weight $\left(\mathrm{g} / \mathrm{m}^{2}\right)$ in unweeded control plot

WDt: weed dry weight $\left(\mathrm{g} / \mathrm{m}^{2}\right)$ in treated plot.

\section{Statistical analysis}

Data were statistically analysed following the procedure given by Gomez and Gomez (2010). Data pertaining to weeds were transformed to square root scale $\sqrt{(\mathrm{X}+2)}$ whenever significant variation existed, critical difference was arrived at five per cent probability level. Such of those treatments where the difference are not significant are denoted as NS.

\section{Results and Discussion}

Influence of time of sowing and weed management methods on Bt cotton

\section{Weeds Interference}

Weed flora of the experimental field consisted of ten species of broad leaved weeds, five species of grasses and a sedge. Dominant among grassy weeds was Cynodon dactylon (L.) Pers. and Trianthema portulacastrum (L.) and Digera arvensis (Forsk.) were the dominant among the broad leaved weeds.

Table 1. Effect of time of sowing and weed management on DMP, number of bolls, boll weight and seed cotton yi eld of Bt cotton hybrid

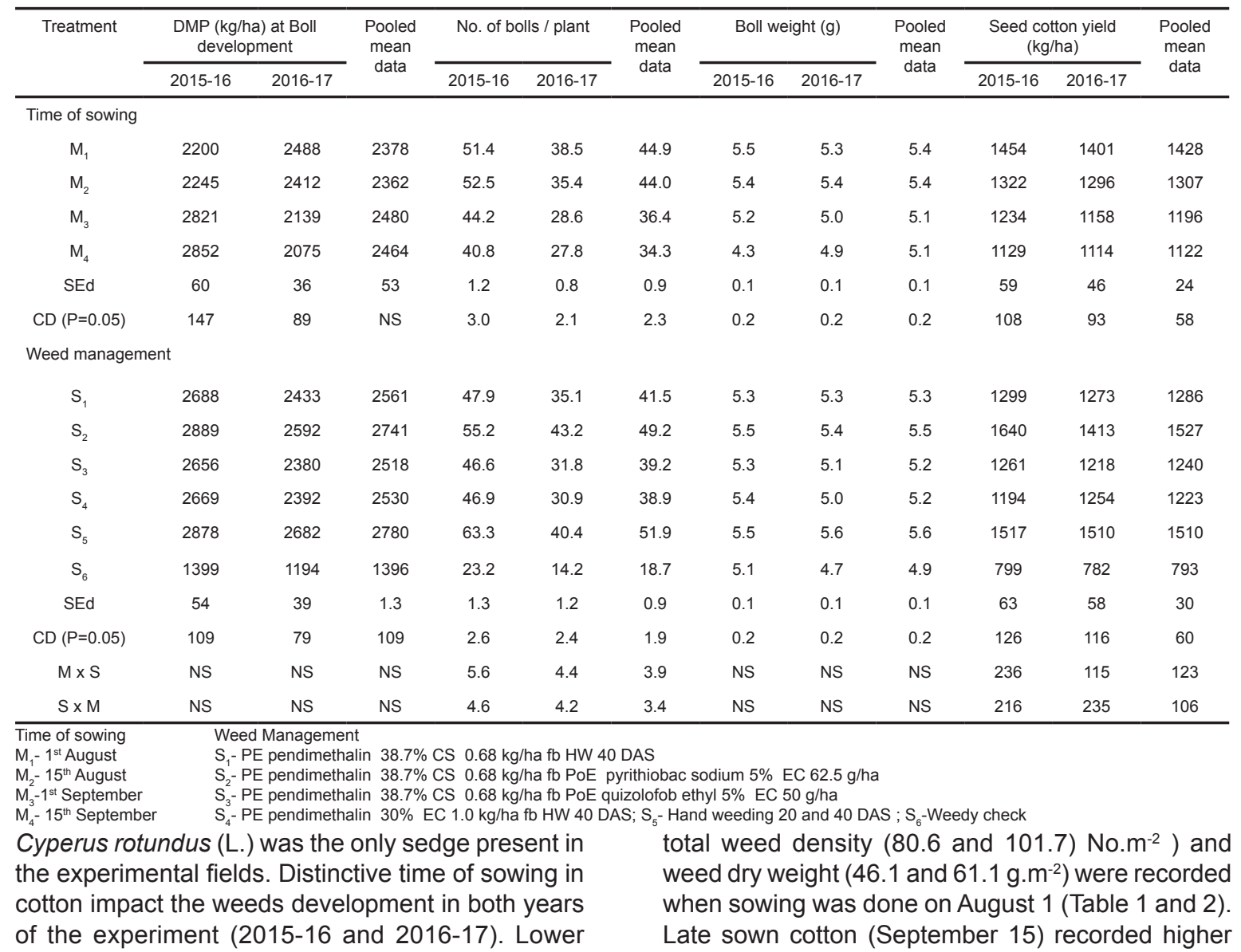


total weed density (113.3 and 120.7 No.m $^{-2}$ ) and weed dry weight (48.58 and 92.2 g. $\mathrm{m}^{-2}$ ) compared to early sown Bt cotton hybrid (1 $1^{\text {st }}$ August) at 40 DAS. It might be, optimum time of sowing provided better vigour to crop and encountered lesser weed competition. Similar results were earlier reported by
Malik and Ashok Yadav (2014) who had found that density of weeds increased significantly with delay sowing in pigeon pea.optimum time of early sowing in pigeon pea provided better vigour to crop and it also encountered less weed competition consequently resulting into higher productivity.

Table 2. Effect of time of sowing and weed management on weed control efficiency at 40 DAS, net return and BCR of Bt cotton hybrid

\begin{tabular}{|c|c|c|c|c|c|c|c|c|c|}
\hline \multirow[t]{2}{*}{ Treatments } & \multicolumn{2}{|c|}{$\begin{array}{c}\text { Weed control efficiency } \\
(\%)\end{array}$} & \multirow{2}{*}{$\begin{array}{l}\text { Pooled } \\
\text { mean } \\
\text { data }\end{array}$} & \multicolumn{2}{|c|}{ Net return(Rs./ha) } & \multirow{2}{*}{$\begin{array}{l}\text { Pooled } \\
\text { mean } \\
\text { data }\end{array}$} & \multicolumn{2}{|c|}{ BCR } & \multirow{2}{*}{$\begin{array}{c}\text { Pooled } \\
\text { mean } \\
\text { data }\end{array}$} \\
\hline & $2015-16$ & $2016-17$ & & $2015-16$ & $2016-17$ & & $2015-16$ & $2016-17$ & \\
\hline$M_{1}$ & 61.1 & 63.7 & 62.4 & 39227 & 36067 & 37647 & 1.81 & 1.74 & 1.78 \\
\hline $\mathrm{M}_{2}$ & 53.4 & 61.7 & 57.5 & 31337 & 29757 & 30547 & 1.65 & 1.61 & 1.63 \\
\hline $\mathrm{M}_{3}$ & 55.2 & 62.3 & 58.7 & 26017 & 21507 & 23762 & 1.54 & 1.44 & 1.49 \\
\hline $\mathrm{M}_{4}$ & 52.5 & 60.6 & 56.5 & 19737 & 18867 & 19302 & 1.41 & 1.39 & 1.40 \\
\hline \multicolumn{10}{|c|}{ Weed management } \\
\hline $\mathrm{S}_{1}$ & 69.0 & 63.5 & 67.6 & 28302 & 26772 & 27537 & 1.57 & 1.54 & 1.56 \\
\hline $\mathrm{S}_{2}$ & 80.2 & 88.6 & 84.0 & 52340 & 38705 & 45523 & 2.14 & 1.84 & 1.99 \\
\hline $\mathrm{S}_{3}$ & 73.8 & 87.4 & 80.4 & 29832 & 27282 & 28557 & 1.65 & 1.60 & 1.63 \\
\hline $\mathrm{S}_{4}$ & 60.5 & 58.4 & 60.1 & 21084 & 24789 & 22937 & 1.42 & 1.49 & 1.46 \\
\hline $\mathrm{S}_{5}$ & 49.8 & 65.9 & 60.8 & 36708 & 36258 & 36483 & 1.68 & 1.67 & 1.68 \\
\hline$S$ & 0 & 0 & 0.0 & 6213 & 5493 & 5853 & 1.15 & 1.13 & 1.14 \\
\hline $\begin{array}{l}\text { Time of sowing } \\
M_{1}-1^{\text {st }} \text { August } \\
M_{2}-15^{\text {th }} \text { August } \\
M_{3} 3^{-11^{\text {st }} \text { September }} \\
M_{4}-15^{\text {th }} \text { September }\end{array}$ & $\begin{array}{l}\text { Weed Managen } \\
\mathrm{S}_{1}-\mathrm{PE} \text { pendime } \\
\mathrm{S}_{2}-\mathrm{PE} \text { pendime } \\
\mathrm{S}_{3}-\mathrm{PE} \text { pendime } \\
\mathrm{S}_{4}-\mathrm{PE} \text { pendime }\end{array}$ & $\begin{array}{l}\text { lin } 38.7 \% \text { CS } 0 \\
\text { lin } 38.7 \% \text { CS } 0 \\
\text { lin } 30 \% \text { EC } 1.0\end{array}$ & $\begin{array}{l}\text { g/ha fb PoE } \\
\text { ga fb PoE } \\
\text { gf HW } 40\end{array}$ & $\begin{array}{l}\text { obac sodium } \\
\text { fob ethyl } 5 \% \\
3_{5} \text { - Hand weec }\end{array}$ & $\begin{array}{l}\text { EC } 62.5 \mathrm{~g} / \mathrm{ha} \\
50 \mathrm{~g} / \mathrm{ha} \\
20 \text { and } 40 \mathrm{DA}\end{array}$ & -Weedy ch & & & \\
\hline
\end{tabular}

In weed management, pre-emergence application of pendimethalin $38.7 \%$ CS $0.68 \mathrm{~kg} /$ ha followed by post emergence pyrithiobac sodium $5 \%$ EC $62.5 \mathrm{~g} /$ ha significantly recorded lower total weed density (48.0 and 99.9 No. $^{-2}$ ) weed dry weight (21.68 and

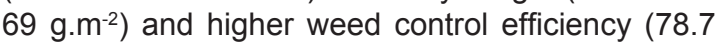
and $89.7 \%$ ) (Fig. 1). Higher total weed density (205.2 and $273.2 \mathrm{No}^{-2}$ ) and weed dry weight (104.2 and 202.1 $\mathrm{g}^{\mathrm{m}} \mathrm{m}^{-2}$ ) were recorded in unweeded check $\mathrm{n}$ both year of the study. It is mainly due to sequential application of herbicides along with inter cultivation could be attributed to weed free situation during initial stages and further control of new flush of weeds by application of post emergence herbicides at 30-35 DAS followed by inter cultivation at 60 DAS and thus, reducing the weed competition during critical initial to peak growth period of Bt cotton. The results are in corroboration with the findings of Hiremath et al. (2013) who had found that pre emergence application of pendimethalin $38.7 \%$ CS $1.5 \mathrm{~kg} / \mathrm{ha}$ fb pyrithiobac sodium $10 \%$ EC $1.25 \mathrm{~kg} /$ ha with intercultivation at 60 DAS reregistered the lower weed dry matter, weed index in cotton.

Table 3. Growing degree days of Bt cotton in different dates of sowing in various stages

\begin{tabular}{|c|c|c|c|c|c|c|c|c|}
\hline Phenological Stages & \multicolumn{4}{|c|}{ GDDs (2015-16) } & \multicolumn{4}{|c|}{ GDDs (2016-17) } \\
\hline Planting to emergence & 122 & 123 & 127 & 130 & 128 & 125 & 113 & 119 \\
\hline Emergence to first square & 373 & 381 & 375 & 362 & 364 & 355 & 360 & 360 \\
\hline Square to flowering & 259 & 241 & 241 & 216 & 241 & 241 & 240 & 232 \\
\hline
\end{tabular}

Productivity and profitability

Seed cotton yield (1454 and $1401 \mathrm{~kg} / \mathrm{ha}$ ) was the higher with cotton sown on $1^{\text {st }}$ August and was significantly superior to other dates of sowing $\left(15^{\text {th }}\right.$ August, $1^{\text {st }}$ and $15^{\text {th }}$ September) during both the years. There was a progressive reduction in seed cotton yield for every successive fortnightly shift in sowing dates from $15^{\text {th }}$ August to $15^{\text {th }}$ September and also earliest sowing of $1^{\text {st }}$ August in both years. Seed cotton yield of Bt cotton (Table 1 and 2) was reduced drastically when the sowing was delayed beyond $15^{\text {th }}$ August. It might be due to the reduction of cumulative GDDs under delayed sowing in all the phenological stages (Table 3). Early sowing of ( $1^{\text {st }}$ August) recorded higher cumulative GDDS of 1314 and 1323 compared to delayed sowing on $15^{\text {th }}$ September (GDDs 1189 and 1212). Optimum heat unit system (GDDs) facilitated cotton through higher photosynthesis, which might have led to higher plant height, dry matter production, sympodial branches, 


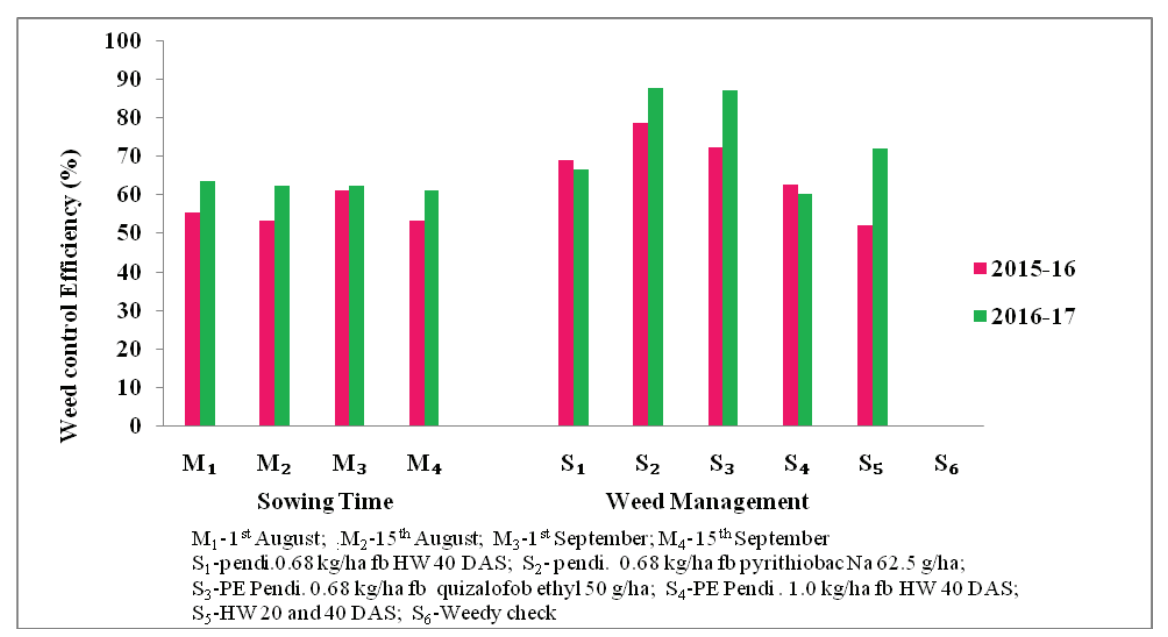

Fig.1. Effect of time of sowing and weed management on weed control efficiency (\%)

bolls/plant and seed cotton yield as compared to late sown Bt cotton hybrid. Buttar et al. (2010) also observed that under Punjab condition, higher seed cotton yield was obtained in early sown American cotton ( $G$. hirsutum) as compared to late sown.

In weed management, first year study (2015-16), pre-emergence application of pendimethalin $38.7 \%$ $\mathrm{CS} 0.68 \mathrm{~kg} / \mathrm{ha}$ fb post emergence pyrithiobac sodium $5 \%$ EC $62.5 \mathrm{~g} / \mathrm{ha}$ recorded higher seed cotton and it was comparable with hand weeding twice on 20 and 40 DAS. During winter 2016-17, higher seed cotton yield was observed in hand weeding treatment and it was on par with pendimethalin $38.7 \%$ CS $0.68 \mathrm{~kg} / \mathrm{ha}$ fb pyrithiobac sodium $5 \%$ EC $62.5 \mathrm{~g} / \mathrm{ha}$. (Table 1 and 2). Advance sowing of cotton on $1^{\text {st }}$ August with weed management practices of PE pendimethalin $38.7 \%$ CS $0.68 \mathrm{~kg} / \mathrm{ha}$ fb POE pyrithiobac sodium 5\% EC 62.5 $\mathrm{g} / \mathrm{ha}$ recorded maximum net return (Rs. 52340 and $38705 /$ ha) and $B$ : $C$ ratio (2.14 and 1.84). Whereas, minimum $B$ : $C$ ratio (1.15 and 1.13$)$ was recorded in weedy check with delayed sowing of cotton (Table 1and 2) in both year (2015-16 and 2016-17) of the experiment. It might be due to increased seed cotton yield due to least weed competition throughout growing season under the influence of sequential use of PE and POE herbicides with one inter-culture operation with lesser cost of cultivation. The results are in line with the findings of Prabhu et al. (2012) and Hiremath et al. (2013). Who had earlier reported that pre emergence application of pendimethalin $38.7 \%$ CS1.5 kg /ha fb pyrithiobac sodium 10\% EC $1.25 \mathrm{~kg} /$ ha with intercultvation at 60 DAS recorded higher seed cotton yield, gross and net returns.

\section{Conclusion}

From results it could be concluded that, early sowing of cotton on $1^{\text {st }}$ August with higher GDDs decreased the weed interaction accompanied by integrated weed management of pre emergence application of pendimethalin $38.7 \%$ CS $0.68 \mathrm{~kg} / \mathrm{ha}$ followed by post emergence pyrithiobac sodium $5 \%$
EC $62.5 \mathrm{~g} / \mathrm{ha}$ resulted higher weed control efficiency, seed cotton yield, net retun and $\mathrm{B}$ : $\mathrm{C}$ ratio.

\section{References}

Buttar, G.S., Paramjit Singh and Parminder Singh. 2010. Influence of date of sowing on the performance of American cotton (Gossypium hirsutum L.) genotypes under semi-arid region of Punjab. J. Cotton Research and Development. 24(1): 56-58.

Dason, A.A., Krishnasamy, S., Ramakrishnan., Y.S and Krishnadoss, D. 1996. Cotton Growing Environment. Agricultural Research Station, Kovilpatti, Tamil Nadu Agricultural University, Coimbatore.

Gomez, K.A. and Gomez, A.A. 2010. Statistical Procedures for Agricultural Research.Wiley India Pvt. Ltd., New Delhi.

Hebbar, K.B., Venugopalan, M.V., Khadi, B.M and Agarwal, P.K. 2007. Impact from climate change on cotton production (abstracts). National Conference on Impact of Climate Change with Particular Reference to Agriculture , during 22-24 August organized by Agro-Climate Research Centre, Tamil Nadu Agricultural University, Coimbatore.

Hiremath, R., Gurappa, S., Yadahalli Basavaraj, M., Chittapur., Ayyanna, D., Siddapur., Vidyavathi, G., Yadahalli Bheemasen Rao and Koppalkar. 2013. Efficacy of chemical weed management in Bt cotton (L.). Acta Biologica Indica. 2(2): 425-429.

Jones, M. and Wells, R.1998. Fiber yield and quality of cotton grown at two divergent population densities. Crop Science. 38: 1190-1195.

Mani, C.L., Michael, A.J. and Murdock, E.C. 2007. Weed Response and Tolerance of Enhanced Glyphosate Resistant Cotton to Glyphosate. J. Cotton Sci., 11(2): 104-109.

Malik, R.S. and Ashok Yadav.2014. Effect of sowing time and weed management on performance of pigeonpea. Indian J. Weed Science. 46(2): 132-134.

Prabhu, G., Halepyati, A.S., Pujari, B.T and Desai, B.K. 2012. Weed management in Bt cotton (Gossypium hirsutum.) under irrigation. Karnataka J. Agric. Sci., 25(2):183-186.

Rajiv Sharma.2008. Integrated weed management in field crops. Crop Care. 35 (4): 41-46.

Zhang. L., Van der Werf W., Zhang, S., Li, B., and Spiertz J.H.J. 2008.Temperature mediated developmental delay may limit yield of cotton in relay intercrops with wheat. Field Crops Research, 2008; 106 (3): 258-26. 